\title{
Inspiration from the Development of Public Administration in the West for Studies of Public Administration in Cbina
}

\section{Lisheng Dong*}

https://doi.org/10.31297/hkju.19.1.2

UDK 35.071.1(510)

Review scientific paper / pregledni znanstveni rad

Received / primljeno: 12. 6. 2018.

Accepted / prihvaćeno: 22.11.2018.

Over the last four decades, PA research in China has resulted in the restoration of the discipline, a flourishing of teaching and research programmes, and active exchanges with colleagues around the world. However, Chinese public administration is facing an "identity crisis". Chinese scholars have become used to playing the role of consumers of imported concepts, theories, and methods. The urgent task at this stage is for China to develop its own unique paradigm, including concepts, theories, and methodologies, and to contribute to the progress of the whole discipline. The goal of forming their own theoretical framework is urging our Chinese colleagues to challenge themselves in order to consciously engage in independent theoretical thought. More specifically, they should try to keep abreast of theoretical developments in the West and lay emphasis on cutting-edge

* Lisheng Dong, Professor of Asian Politics, University of Tartu, Estonia (redoviti profesor na Sveučilištu u Tartuu, Estonija, e-mail: lisheng.dong@ut.ee).

ORCID ID: https://orcid.org/0000-0002-3810-6455 
research, avoid not seeing the forest for the trees, and practise timely adoption of dominant theories.

Keywords: public administration theories, China, the West, tradition, reform and opening up, imitation, indigenisation

\section{Introduction ${ }^{* *}$}

Many of my reflections, findings, and thoughts from two decades of teaching and research on public administration theories and practices are related to my deliberation of the consequences of China's recent development strategy (Dong, 2015). Policies in some social spheres were created by superficial understanding or misunderstanding of Western administrative theories.

The reform and drive to open up, as initiated by Deng Xiaoping in 1978, have profoundly changed Chinese society and people's livelihoods. Deng (1994, p. 152) famously argued that it would be necessary for some people to "get rich first". Since 1989, there have been trade-offs between the different objectives of development and stability (Jing, 2009). The party-state's guiding principle gives priority to efficiency with due consideration of fairness (Central Committee, Communist Party of China, 1993). However, for a certain period of time equality was neglected in some social strata and sectors. The pace of economic development was rapid and consistent, with GDP growth at around 10 per cent for three decades until 2010, and this has elevated China to the status of the world's second largest economy.

However, following two decades of reform, many problems arose in relation to marketisation: corruption of officials, unaffordable housing and healthcare, increased inequality, toxic drugs and food, and environmental deterioration beginning in the mid-1990s (Liu \& Li, 2013). Rising social polarisation brought about social unrest. The situation calls for a new development model in which economic development can be balanced with other social objectives. In recent years, the government has placed greater emphasis on the "scientific approach to development" and the development of a "harmonious society", which has led to the introduction of

** This research was supported by a Marie Curie International Incoming Fellowship within the $7^{\text {th }}$ European Community Framework Programme, Project Number 626590 and by the University of Tartu, ASTRA Project PER ASPERA, financed by the European Regional Development Fund. 
various public services not available previously. As a result, the emphasis on short-termism has consequently been reduced, particularly when it is likely to undermine long-term sustainability.

Administrative reforms have followed a similar path to the interaction between development and stability. In the early stage of administrative reforms, marketisation was introduced on a large scale across the policy domains of education, health, and housing. For example, many patients in China had to pay a much higher percentage of their medical bills than those in numerous other countries in the 1990s and early 2000s, which resulted in widespread complaints about the marketisation of China's healthcare system (Dong et al., 2014). While some argue that these changes reflect the reforms associated with the New Right and New Public Management movements in the West, they were also driven by a lack of sufficient financial and administrative resources required by the state to provide these services (Christensen et al., 2009). In recent years, efforts have been made to reverse this trend in the new National Health System Reform that has reintroduced the role of the state as a major financier of the healthcare system (Dong et al., 2014).

In short, China has embraced a variety of reforms over recent decades, which have neither been thoroughly theorised nor empirically examined. This is a reflection of the status of the field of public administration in China. Public administration as a discipline was restored in China in the mid-1980s. After the founding of New China in 1949, misconceptions about academic research led to the cancellation of public administration departments in higher education institutions, as was the case with many other social science disciplines (Wu et al., 2016). The few existing public administration scholars shifted their teaching and research interests to fields such as Marxism and Leninism, ideology building, and history. Against this background, it is understandable that conducting empirical research aimed at developing and testing various hypotheses has just begun to emerge in the last decade or so (Xue et al., 2008; Wu et al., 2013).

It is against this background that I found it necessary to engage in thorough study of administrative theories in the West. The reason is that many Western-based theories of public administration have some traction in the Chinese setting (Christensen et al., 2012). However, they also point to the importance of context and the need to ensure that the theory is relevant to the setting. In this regard, theory needs to be both clearly developed and there are various routes that can be taken. In this paper I would like to share with the readers some of my thoughts emanating from my research for my new book, namely, inspiration from the development of 
public administration in the West for studies of public administration in China. It is my sincere hope these will be of some referential value to our Croatian colleagues in their efforts to promote the teaching and research of public administration in Southeastern Europe.

Before presenting my review of the field in China, it may be necessary to give a description of the analytical lens which I used for the book. My book is innovative in that it offers a comprehensive interpretation of the instrumental rationality and the value rationality of public administration, and an all-round insight into the evolution of public administration theories in the West through the five main dimensions of core value, assumptions about human nature, methodology, government role, and disciplinary positioning. It should be noted that the five dimensions are closely related to public administration and pivotal in its theories and practices (for details, see Dong, 2015, Introduction).

As I explain in the book, existing research into the history of public administration theories in the West mainly approaches the topic from the following perspectives: development stages, schools of theories, research paradigms, research routes, and the like. All of these are of certain value, yet they fail to reveal the fundamental nature of the various schools of thought in the development of public administration: the instrumental and value rationalities. The instrumental rationality emphasizes efficien$\mathrm{cy}$, while the value rationality focuses on equity and equality. The differences and contentions between the two promote the development and evolution of public administration theories. Various schools of public administrative theories can be grouped together into the two camps of value and instrumental rationalities. From the perspective of the developmental process of public administration theories, the two camps have alternated in terms of dominance, demonstrating pendulum movements. An analysis of these movements can clarify the development routes of public administration theories in the West (for details, see Dong, 2015, Introduction).

\section{A Brief Overview of the Two Relevant Concepts}

In order for readers to appreciate what I put forth as inspiration stemming from the development of public administration theories in the West for studies of public administration in China, here I briefly review the two basic concepts of the five elements and pendulum movements in the development of Western public administration theories. 


\subsection{Five Essential Attributes of Public Administration}

To begin with, core value is the soul of public administration. It is the ultimate goal or concept of action running through the entire process of public administration and is an important component of administrative philosophy. From the perspective of administrative practices, core value directly influences the setting of government goals and therefore has an impact which cannot be ignored on the thoughts, ideas, and behavioural patterns of civil servants. In terms of academic research, core value determines the fundamental direction, main contents, and research methods of public administration studies. It is an important identity mark of different academic schools of public administration. From the perspective of the thoughts of different academic schools, core value is the most essential content that differentiates any school from the rest, and it is also the basis of each independent school.

Second, assumptions about human nature form the logical starting point of public administration. They refer to the selective abstraction and reflection on the performance of civil servants or the general public in accordance with a certain value orientation. Generally speaking, social sciences and humanities often regard certain assumptions about human nature as "postulates" and build on them to infer and establish theoretical systems (Zhou, 2000, p. 1). In public administration theories, different assumptions about human nature constitute different public administration systems alongside different logical structures. Not only do they form different measures and methods of public administration, but they also have important impacts on organisational structures and forms. For public administration, assumptions about human nature constitute a prerequisite for theoretical construction, policy recommendations, and implementation of measures. Analysing the assumptions about human nature in various schools of public administration studies may help people achieve a clear understanding of the thoughts of the schools.

Third, methodology is the pivot of public administration studies. Methodology, the framework of a certain subject or theory, is a significant way of measuring the maturity of a certain discipline or branch of learning and determines its scope, depth of thought, and, to some degree, potential. Public administration research methods occupy an important place in traditional and contemporary public administration theories or paradigms. In a manner of speaking, the maturity and development of public administration research methods has an immediate impact on the scientific, ra- 
tional, and realistic development of public administration (He Ying 2005, p. 104). Over 120 years of history of public administration prove that it is the constant updating of methodology that provides abundant analysis tools, research methods, and management technology of studies in the field. It has also prompted the development of public administration in leaps and bounds, improving its studies and rendering them more scientific.

Each subject has its own research methods, and methodology reveals the basic approach of different subjects and schools and is an important dimension to mark off subjects and schools. From the perspective of scientific research, content and methodology are supplementary to each other. The analysis above tells us that methodology is of great importance for helping people to know the ideology of each school of public administration and the significance of its feasibility.

Fourth, the role of the government is a concrete manifestation of the public administration function in practice. It refers to what the government should do to promote good governance and economic and social development, as well as to its responsibilities in public administration. The manifestation of the public administration function as it is practiced by the government is concerned with relationships between the government and political parties, between the government and the market, and between the government and society. It makes studies of the field a basic subject of public administration and an inevitable issue of the scholars involved, together with the special status of government in public administration.

In the realm of public administration, public is a synonym for government (Frederickson 2003, p. 19). From this definition, it can be determined that public administration is the study of government management. Different schools of public administration hold various views about what the government should do to promote good governance and economic and social development. The government role positioning embodies policy suggestions of different schools. Therefore, understanding the government role is the core factor in understanding the various ideologies of public administration schools.

Finally, disciplinary positioning determines the development tendency of public administration studies. Having reached a certain stage, public administration will gradually mature as an independent branch of learning, and the next basic and major issue is its positioning. Disciplinary orientation engages with various concrete issues, including research contents and methods of public administration, construction of the subject system, 
and talent training. Hence one can see that disciplinary positioning is of great significance in developing public administration, and research of disciplinary positioning can assess the tendencies of the subject, making it meaningful for further public administration studies.

The five dimensions above summarise the principal characteristics of the different schools of public administration in the West. Studying the different schools from the perspective of these dimensions helps provide people with a general idea of public administration. It also holds a certain degree of importance in promoting public administration studies.

\subsection{Pendulum Movements in the Development of Public Administration Theories in the West}

The pendulum movement is mainly found in physics, although it also exists in other disciplines. For example, it may be observed in fiscal policy swings between expansion and shrinkage, in the relationship between the government and the market swaying between interference and laissez-faire, and in central-local government relations, oscillating between centralisation and decentralisation.

The pendulum movement in the development of public administration theories differs from the pendulum movement of physics. In the latter, the pendulum is static without outside interference. Once pushed, the pendulum swings, and the greater the force, the greater the range of movement. Due to gravity, the movement will slow down until it has returned to a constant state. A clock's pendulum swings around a central point and within a range.

The pendulum movement in the development of public administration theories in the West refers to these theories being, in a certain period of time, situated at one end of their movement trajectory (either far to the left or far to the right). When a series of problems occurs, theories shift towards the other end (either far to the right or far to the left). The development of public administration theories in the West has been swaying between the two endpoints. With time, such swings decrease in range and move towards the lowest point. In general, the pendulum movement in the development of public administration theories possesses the following three characteristics: (1) the left endpoint represents the school with the most obvious value rationality, i.e., New Public Administration, (2) the right endpoint represents the school with the most obvious instrumental rationality, i.e., Traditional Public Administration, and (3) the lowest 
point represents the merger of the value and instrumental rationalities. All schools swing between the left and right endpoints and move toward the lowest point.

The alternation process of Western public administration theories can be simplified as follows:

1. 1887-1968: the Traditional Public Administration Theory occupied the dominant position amongst Western public administration theories. This period began in 1887, when Wilson published his Study of Administration. Besides Wilson, representative figures and works of this school also include Taylor with The Principles of Scientific Management (1911) and Weber with Economics and Society (1921-22). Of all the schools of Western public administration theories, this theory is the most obvious in its instrument-rationality orientation.

2. 1968-1979: the New Public Administration Theory enjoyed the dominant position amongst Western public administration theories. This period began in 1968, when the Minnowbrook I Conference was convened. Its representative was Fredericksen, whose works include New Public Administration (1980) and The Spirit of Public Administration (1997). Of all the schools of Western public administration theories, this theory is the most obvious in its value-rationality orientation.

3. 1979-1987: the Privatisation Theory dominated amongst Western public administration theories. This period commenced after the inauguration of President Reagan, who launched a privatisation campaign. Many public administration scholars regard this as the emergence of New Public Management (NPM). However, I view it as only a harbinger of NPM and hence the Privatisation Theory is dealt with separately. Its representative figure is E. S. Savas, whose works include Privatizing the Public Sector: How to Shrink Government (1982) Privatization and Public-Private Partnerships (2000). Although the instrument-rationality oriented Privatisation Theory was prevalent in this period, its instrument rationality was lower than that of Traditional Public Administration.

4. 1987-1991: the Democratic Administration Theory was dominant. This school of thought comprises three groups of scholars: the Blacksburg School members, the advocates of Democratic Administration represented by Ostrom, and the participants of the Minnowbrook II Conference. In 1982, the Blacksburg School, represented by Wamslay, Wolf, and Goodsell, presented their Public Administration and Governance: The Transformation of American Political Dialogue, namely, the Blacksburg Manifesto. In 1987, the Manifesto was printed for the first time in A Centen- 
nial History of the American Administrative State. This can be regarded as moment when the school of value rationality regained the dominant position. Thereafter, scholars belonging to this school published a number of works. Representative figures and works of this school include The Public Administration and the Governance Process: Shifting the Political Dialogue (Wamsley et al., 1982), Reconstruction of Public Administration (Wamsley et. al., 1990), and Intellectual Crisis in American Public Administration (Ostrom, 1973). Its value rationality was lower than that of the New Public Administration Theory.

5. 1991-1996: the New Public Management (NPM) Theory was dominant amongst Western public administration theories. The beginning of this period was marked by the first American Public Management Symposium convened at Syracuse University in 1991. The broad connotation of NPM includes the Privatisation Theory and Reinventing Government Theory. Here the narrow connotation of NPM is used; namely, Privatisation Theory is not included. Representative figures and works of this school include A Public Management for All Seasons? (Hood, 1991), Re-inventing Government: How the Entrepreneurial Spirit Is Transforming the Public and Private Sectors (Osborne \& Gaebler, 1992), and In Introduction to Public Management (Hughes, 1994). Compared to the Privatisation Theory, NPM pays greater attention to equity on the basis of advocating for instrument rationality. Hence its instrumental rationality is lower than that of the Privatisation Theory.

6. 1996 to the early 21st century: the New Public Service Theory gained prominence in Western public administration theory. This period was ushered in by the publication of Public Administration, Public Service and Democratic Citizenship by Denhart in 1996. Another publication which is representative of this school is The New Public Service: Serving Rather than Steering (Denhardt \& Denhardt, 2007). Compared to the Democratic Administration Theory, the New Public Service Theory is lower in value rationality, while its instrumental rationality is somewhat stronger.

7. Since the end of the 20th century: the Holistic Governance Theory originated in 1997, when Perri published Holistic Government. He also published Governing in the Round: Strategies for Holistic Government (1999) and Towards Holistic Governance: The New Reform Agenda (2002). This theory attracted the same level of attention as the Public Value Management in the early 21st century. Compared to NPM, Holistic Governance cares more about the merger of the instrument and value rationalities. On the basis of instrument rationality, it strives to converge with the value rationality. 
8. Since the early 21st century: Public Value Management came to prominence in 1995, when Mark H. Moore published Creating Public Value: Strategic Management in Government. He also published Public Value: Theory and Practice (2010) and Recognizing Public Value (2013) As noted previously, this theory goes hand in hand with the Holistic Government Theory in the early 21st century. Compared to the New Public Service Theory, the Public Value Management Theory cares more about the merger of the value and instrument rationalities. On the basis of value rationality, it strives to realise a merger with the instrument rationality.

Figure 1. Illustration of the Pendulum Movement in the Evolution Process of Western Public Administration Theories

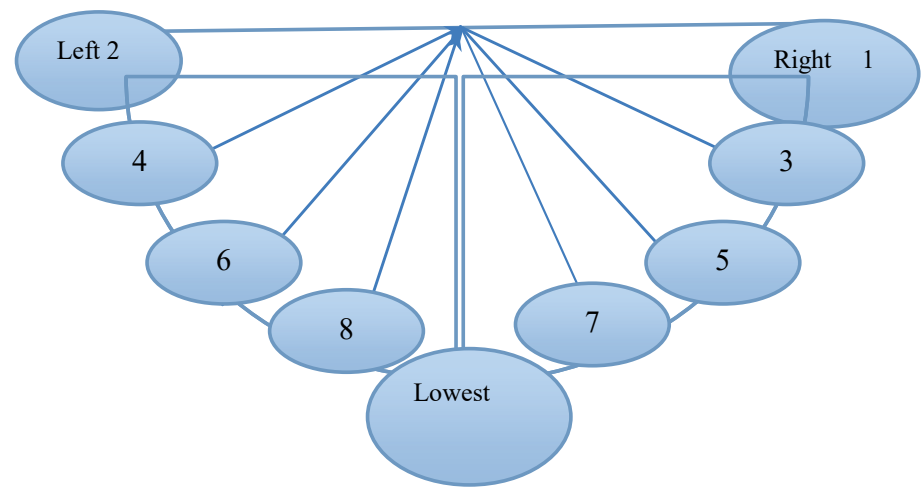

Source: Author

Notes:

Right side = Instrumental rationality camp: 1. Traditional Public Administration, 3. Privatisation, 5. New Public Management, and 7. Holistic Governance

Left side = Value rationality camp: 2. New Public Administration, 4. Democratic Administration, 6. New Public Service, and 8. Public Value Management

Lowest point $=$ merger of two rationalities.

In Figure 1 we can see that in the pendulum movements of Western public administration theories, as far as the instrumental-rationality oriented theories are concerned, Traditional Public Administration Theory is situated at the right endpoint, Privatisation Theory is located between the right endpoint and the lowest point but is closer to the right endpoint, New Public Management Theory sits exactly between the right endpoint and the lowest point, and Holistic Governance Theory is close to the lowest point from the right side. Of the value-rationality oriented theories 
New Public Administration Theory sits on the left endpoint, Democratic Administration Theory is situated between the left endpoint and the lowest point but is closer to the left endpoint, New Public Service Theory is located between the left endpoint and the lowest point, and Public Value Management Theory is close to the lowest point from the left side.

\section{Inspiration from the West for Public Administration Development in China from the Perspective of the Five Elements}

Western administrative theories were an inspiration for public administration research in China. In this section, these theories are presented from the perspective of the five elements as described in the previous section.

\subsection{Core Value: Efficiency and Public Spirit}

In recent decades, studies of public administration science in China have basically been oriented towards the efficiency principle (Bo, 1998), embraced the "managerialism" mindset (Yan \& Niu, 2009), and rarely touched on value issues such as equity, justice, and citizens' rights, which are closely related to politics and the public spirit. As a result, people have failed to realise the value or political philosophy behind existing public administration practices and theories, or even that there are other possibilities besides the current experience (Ma \& Liu, 2007) or "big issues" regarding public administration science (He, 2008, p. 37). Within this mindset, public administration is understood as a management technique or craft which requires efficiency, the function of public administration is positioned as policy execution, and the science of public administration becomes a subject studying techniques only, devoid of "public nature". Therefore, the biggest problem with public administration in China, be it related to theoretical studies or practice, is the absence of a "public nature" (Zhang, 2007), which jeopardises the legitimacy of the science of public administration. Thus, public administration science in China should put a stop to efficiency-oriented studies and reconstruct its public component. It needs to provide accurate and comprehensive explanations for the connotations of concepts such as equity, justice, participation, and public interests that involve the public spirit, and transfer them from the 
ruling or political scope to the administrative or governance scope. This could address the legitimacy crisis of the science of public administration and keep it separate from political science, making it more independent.

Given the current situation in China, problems of corruption and government efficiency have become increasingly prominent as economic reform has deepened. In this context, it is of certain practical meaning to reconsider the core value of public administration. From the history of theoretical development the science of public administration has undergone in the West, it is clear that there is a tendency for instrumental rationality and value rationality to achieve mutual integration. These changes present a warning for Chinese public administration researchers to consider not only how to build an efficient government, but also topics concerning value judgements such as "what is good government".

\subsection{Assumptions About Human Nature: Diversity of Human Nature}

Under the influence of traditional culture, public administration design in China has adopted completely different assumptions about human nature with regard to government officials than with regard to the general public. As regards government officials, the assumption about good human nature is adopted, which allows government officials to mobilise resources for grand projects and provide window dressing for the "advantages of socialism". However, this also makes it easy for government officials to become corrupt and makes them more likely to make wrong decisions and serious errors and cause social disturbance, such as the Cultural Revolution. As for the general public in China, especially since the implementation of the Reform and Opening-Up Policy, the logic of evil human nature has been adopted to manage people. Such management logic is important for maintaining social stability, but it suppresses the motivation of the public and leads to administrative apathy, which, in the long run, is bad for the sustained development and stability of the society. Therefore, in the future, studies of public administration science in China should change such assumptions about human nature. As for government officials, we must be aware that they are like ordinary people, have desires and feelings, and make mistakes. In the public sector, their behaviour as an economic man, seeking to further their own interests, will not produce the order of the economic market that reflects all the interests of all participants, but will only lead to bureaucratism, low government effi- 
ciency, and corruption (Zhang, 2002, p. 159). We should therefore adopt the assumption about evil human nature when constructing systems and mechanisms to prevent officials from abusing their power. However, such institutional design tends to kill the initiative and creativity of officials and dampen their morale. As the American philosopher Edgar Bodenheimer said, while employing some systems that serve useful purposes, people might go beyond the legal scope of these systems and under certain historical conditions, might turn management into enforcement, and control into suppression (Bodenheimer, 1999, p. 404). Thus while promoting values, we should require officials to act according to the code of conduct of the moral man, become civil servants, serve the people whole-heartedly, respect them, and make them feel that being a government official is a noble profession. As regards ordinary people, we should change our prejudice that they are unruly and instead treat them as citizens and guide them to participate in public affairs in a progressive and orderly way. This is a major task for studies of public administration science in China.

\subsection{Methodology: Norms and Empirical Research}

Methodology is a key indicator for measuring how developed an academic subject is and for determining its growth potential and profoundness, but public administration science in China pays little attention to research methods (Cheng, 2011). Zhang Mengzhong and Marc Holzer once commented on the research methods of public administration science in China in the preface to the "Public Administration Research Methods" column of the journal Chinese Public Administration as follows: "The current research methods are still in the initial stage of a manual workshop; the research on public administration methodology is rare ... The current teaching of public administration, in particular the senior degree education, barely covers the methodology or research methods and much less published works and papers present research results on methodology." (Holzer, 2001). From the empirical point of view, public administration studies in China prefer deductive reasoning and concept analysis, lack field surveys and data analyses, and even when field surveys and data analyses are conducted in some studies, they fail to construct a local theory that provides a satisfactory explanation of "Chinese public administration in the real world" due to the absence of scientific research methods (Ma et al., 2009, p. 5). In brief, studies of public administration in China are detached from practice and cannot guide administrative practice. From the perspective of norms, under the influence of the efficiency doctrine, 
studies of Chinese public administration tend to focus more on technical details, while they neglect discussions of major value issues, resulting in inadequacy of public administration. Therefore, to study Chinese public administration, particular attention should be paid to research methods, which should be included in a compulsory course on public administration. Equal attention should be paid to normative research and empirical research. In future studies of public administration in China, most researchers should be engaged in empirical research in order to help people better understand and interpret all kinds of phenomena in the real world, while a small number of scholars should devote themselves to normative research to discuss the most fundamental issues of the subject (Ma, 2012). Some basic concepts in the discussions on research methods in China need to be defined. Social sciences are different from natural sciences. First of all, we need to understand what characterises a scientific research method. There is a common misunderstanding that a quantitative or empirical method is a scientific research method; however, this in fact confuses the concept of science with that of a research method. Science can refer to both natural sciences and social sciences. Some scholars therefore suggest that, "science is the systematic knowledge attained through observation, investigation and experiment for the purpose of determining the nature and pattern of the research object." (Yuan, 1997, p. 3). Here, quantitative and qualitative research methods, such as the statistical method, observation method, interview method, and literature review method can all be applied to natural sciences and social sciences. Scientific methods are not the only way to attain knowledge. Social sciences and natural sciences are distinguished by their respective research object. Social sciences mainly study complex, changing phenomena without standards, and social science research is distinctly characterised by utilising the researcher as an instrument. Therefore, it is inevitably tinged with prejudice and limited understanding, as well as influenced by ethnic cultural backgrounds and class standpoints. Many qualitative research methods are accepted by Western academic circles as scientific research methods, but their calls for a so-called objective and truthful reflection of the research object are simply ethical requirements for researchers and place no constraints on them with regard to interpreting phenomena. This is why there are so many different theories and interpretations of a single phenomenon in the field of social sciences. This is yet another characteristic of the social sciences. The insights gained from these research methods for Chinese scholars are not only to employ empirical methods, but to begin with basic academic requirements such as academic ethics. In public administration research, 
command of basic research methods, including quantitative and qualitative methods, is important, but academic ethics and the provision of a favourable environment for such ethics are even more crucial. Compared with implementing one particular method, it is perhaps more important to allow scholars in the public administration field to be able to obtain true and objective research results, measure and evaluate research results, and allow public administration researchers to grow in a free atmosphere and publish their own results. This is also one of the points advocated at the third Minnowbrook Conference (O'leary, 2011).

\subsection{Government Role: Creator of Public Values}

Compared with government functions, the government role has a narrower and more specific meaning: it refers to the role of administrative organs in the process of public services. In China, under the influence of a planned economy, little research had been done on the government role as opposed to research on the positioning of government functions. However, with the establishment and development of a socialist market economy and under the influence of the international New Public Management movement, the government is no longer the sole public management entity. Many non-governmental organisations have participated in public affairs and research on the government role will surely become a prominent subject. It is therefore necessary to study the government role in China. As to the question of what the government role is, the academic circle in the West has already given a very good answer: it is the creator of public values. This is a major insight for the studies of the Chinese government role. The next step is to apply this theory to the current situation in China. It must be noted that public administration in the West is based on the democratic political system in Europe and the United States, which is hugely different from the political status quo in China. To some extent, Western governments are results of the checks and balances of different interest groups. In the capital-dominated age, the scientific and efficient operation of the government was the mainstream; however, with the popularisation of democracy and the formation of a civil society, citizens' participation in governance and the government's public nature have started to take over the mainstream position. This has led to the emergence of a customer-oriented government and later on visions of the public value management school on the administrative ethics and public values of the government. The changes these academic schools envision/consider nec- 
essary for the government role indicate that with social progress social progress the government will undertake a greater number of roles and receive more extensive supervision. The government role should not be limited to policy execution or merely being the instrument of political parties. Instead, the government needs to undertake the function of guiding and creating public values to a greater extent. The government has inescapable responsibility and obligation in improving society's ethical values.

The concepts of officialdom and hierarchy have taken deep root in China under the influence of the feudal system and Confucian culture, and have long been present in the country. The change of the government role falls within the scope of political reform and it must be realised that this task is demanding and will take a long time. To a certain extent, the emancipation of the mind, the gradual formation of the civil society, and the popularisation of democratic values will play a fundamental role in the transformation of the government role. Meanwhile, political reform will either facilitate or constrain such a transformation. We need to work on the transformation from both the aspect of the social basis and the superstructure.

\subsection{Disciplinary Orientation: Public Governance}

In 1997, the Academic Degree Commission of the State Council and the State Education Commission issued a Catalogue of Disciplines and Majors to Grant Doctoral and Postgraduate Degrees and Provide Postgraduate Programmes, which separated public administration science from political science and included the former within the newly-established First-Grade Discipline - Public Management, under the category of management science. This was an attempt to strengthen the independence of the science of public administration and set it free from political science on the one hand, and to selectively borrow from management science and make public administration science a true discipline of practice on the other. But the effect has failed to live up to expectations: unlike political science, which is like an abusive parent of public management science, management science is more like a distracted nanny, who never knows who is in which room and often forgets to prepare meals (Henry, 2011, p. 39). That is to say, although it has emerged from the mire of political science, the science of public administration has failed to gain a firm foothold in management science and is in danger of being marginalised. It is therefore necessary to reconsider the disciplinary orientation of the science of public administration in China. I believe that we should learn from public 
administration in the West, define its disciplinary orientation as public governance, include it as a First-Grade Discipline within the category of law, and exclude it from management science or political science.

\section{Lessons for China in Terms of the Pendulum Movement in the Development of Public Administration Theories in the West}

This section continues with thoughts on deficiencies in China's circle of public administration scholars and how it could do better. The section focuses on what can be learned from the pendulum movement in the development of public administration theories in the West.

\subsection{Keeping Abreast of Theoretical Developments in the West and Laying Emphasis on Cutting-Edge Research}

In the 1990s, New Public Management and New Public Service emerged in Western public administration circles. In the early 21st century, Holistic Governance advanced at an equal pace with Public Value Management. However, the research results of their Chinese counterparts in recent years show that many researchers remain focused on New Public Management and New Public Service, failing to catch up with the latest developments in the West. If it does not keep pace with cutting-edge global research, it is impossible for China to develop public administration theories relevant to its national conditions, nor is it possible for China to present to the world globally relevant theories with distinctive Chinese characteristics.

The situation Xie Qingkui (1993) lamented two decades ago seems little improved. According to that research on Chinese public administration is either atheoretical or pre-theoretical, research findings cannot serve as a basis for the development of a general (or medium-range) theory of Chinese public administration or Chinese bureaucratic behaviour, and atheoretical or pre-theoretical research contributes very little to the advancement of usable knowledge for problem-solving. He summed up four major fallacies and problems, namely, over-simplification of causes, misformulation of concept, stereotyping, and non-usable knowledge. It was concluded that Chinese scholars should be more theoretically rigorous.

The ways in which research is conducted also requires attention in future studies on China. Only a small proportion of articles reviewed by Wu et 
al. (2013) have met international standards for social sciences (see also Walker et al., 2013). It is possible that of the articles reviewed by Walker et al. and Wu et al. many did not seek to implement or adopt research predicated on Western social sciences, and perhaps wished rather to focus on the "art" of public administration. However, if theories for China are to be developed, they need to be tested, and testing requires methodology. If this position is to be accepted, then scholars will need to engage with debates about methodological positions (in very simple terms: induction versus deduction) and find appropriate ways to develop evidence. Implementing social science research methods in keeping with the standards of leading journals poses a further challenge. Some scholars have examined topics using longitudinal datasets taken from administrative records that are starting to explore questions about causality in public policy and administration (Wang \& Zhao, 2012). However, challenges remain if scholars wish to examine the perceptions of managers and seek to implement surveys based upon random sampling, because of the conflation of administration and politics in China and the role of guanxi (personalised networks of influence) (So \& Walker 2006; Christensen et al., 2012). If these practicalities remain a challenge for academics, they will need to explore the repertoire of research designs and techniques open to social scientists. In particular, experimental techniques based on randomised controlled trials, which are becoming more widely present in public policy and administration, may offer a fruitful way of advancing knowledge (see, for example, John et al. 2011; Walker et al. 2013). Regardless of the way in which scholars seek to advance knowledge in China, it is essential that attention be given to the measurement of variables and concepts. As social scientists seek to operationalise complex concepts to explain our world and make predictions on how we might make improvements, the nostrum that "measurement matters" becomes all the more important. Measurement might be seen as banal, uninteresting, and unimportant, but research findings can be no better than the measures used. Thus, attention needs to be sharply focused on reliable and valid measures.

\subsection{Avoidance of Failing to See the Forest for the Trees}

A search of the key academic website in China, the National Knowledge Infrastructure (CNKI), shows that by July 2014 the research interest of Chinese administrative science scholars had shifted towards theories in 
the instrumental camp. For example, there were 5,843 items for New Public Management; 1,548 for New Public Service; 279 for Holistic Governance; and just 19 items for Public Value Management. These results are in line with China's reality, as noted previously. Since 1978 when the reform and opening-up drive was launched, the policy balance has favoured efficiency at the expense of equality. In China's administrative science circles this is reflected in the prevalence of instrumental rationality theories. In fact, in the West there have been pendulum movements between theories belonging to the two camps of instrumental and value rationalities. Since the beginning of the 21st century, the Chinese party-state has emphasized the need to pay attention to equality. These developments remind Chinese administrative scientists of the need to maintain a balance in the study of theories categorised within the different camps of instrumental and value rationalities. One-sided emphasis on either camp should be avoided. A healthy development of public administration as a discipline in China requires balanced research.

This situation is deplorable, as the moral justification for bureaucracy in systems of democratic self-government is stronger in Eastern thought than in Western philosophy and practice. In East Asia, moral justification for bureaucracy is broadly understood to be based on the work of Confucius and his followers. Modern scholars confirm that the primary countries of East Asia have distinctive bureaucratic cultures which can be traced to Confucian ideology (Frederickson, 2002).

I agree with Margaret Stout $(2006)$ in that we need to ask ourselves about our theoretical lineage. Ideally, as scholars and practitioners, "we should all be able to answer this question to understand our own biases, moral compass, proclivities, strengths, as well as potential blind spots. We should be aware of how theory informs our actions and be mindful in the choices we make."

\subsection{Efforts Should be Made at Indigenisation of Western Public Administration Theories}

A total of 131 years have elapsed since 1887, when Woodrow Wilson published The Study of Administration, thereby marking the establishment of administrative science. It has been 83 years that administrative science was introduced to China, if the publication of The Theories and Practice of Administrative Science by Zhang Jinjian in 1935 is taken as the starting point. However, localisation has not yet been achieved and one reason for 
this seems to be that Chinese scholars have devoted little effort to indigenising this Western discipline. They may be contented at introducing it to China or stagnate at conducting the feasibility study of introducing it to China. Until the 20th century, many countries all over the world had followed the suit of the American public administration. With the advent of the 21st century there have been some changes. Holistic Governance originated in the United Kingdom at the end of the 20th century and began to advance shoulder to shoulder with Public Value Management, which had emerged in the United States. Furthermore, British scholar Patrick Dunleavy formulated the Governance Theory in the Digital Age. These are good examples for Chinese public administration circles as they make an effort to indigenise Western administrative theories and contribute to global administrative theories based on Chinese practice.

As noted previously, public administration was imported into China from Western countries. The influence of international scholarship has never stopped since it was restored as a branch of learning at universities in the early 1980s. Jill L. Tao notes that as indigenous theories of local government behaviour in East Asia are still being developed, many studies (in English) of local government behaviour in China and South Korea are borrowing and testing theories that have been developed in the West. This has led to somewhat unusual findings in the research conducted in these countries, partly because the nature of theoretical assumptions is often misunderstood or not known prior to the attempt to test these theories in new contexts (Tao, 2016, p. 746).

In the field of social sciences, theory-building naturally includes learning from other disciplines and from other countries. In the case of Chinese public administration, there are several other reasons worth mentioning. First, an essential element of reform and an open policy is to learn from the West. As Deng Xiaoping once claimed, "we will learn all possible advanced outcomes worldwide". The process of reform and opening up is also the process of learning from the West. We are learning about advanced technologies, methods, policies, and public administration theories imported from the West. Second, Chinese public administration, due to its interrupted academic tradition, lacks theoretical legacies. When a sudden and significant need for public administration theories, education, and research emerges, there is little time for completely independent and mature theory-building. Learning from the West is a realistic approach of coping with current needs.

In this fast-changing, globalised world, if the study of public administration is decontextualised from its setting, this does not only widen the gap 
between practice and theory, but also decreases the relevancy of administrative science. The negative impact and costs of a disjuncture between theory and practice in a newly industrialised country like China are often greater than in industrialised nations. In newly industrialised countries, their environmental, labour, and social policies as well as governance institutions are often outdated, and social and political reforms are more common compared with industrialised nations. Consequently, newly industrialised countries rely more on public administration theories that fit into their political and social context to guide the reform and policy-making decisions. Therefore, more vigorous efforts need to be invested in China in order for it to further develop empirically based and behaviourally oriented comparative administrative studies.

Zhang and his colleagues have found that public administration research and practice in China have grown considerably over the last 15 years (Zhang et al., 2017). What does this progress mean? Positively speaking, the authors note indicate the improved ability of Chinese administrative scientists to access, read, and refer to foreign academic findings. In the 1980s and 1990s, foreign references cited by Chinese scholars were often outdated ones published in the 1960s or 1970s, but more recently they seem to be keeping up with foreign public administration by frequent citations of the latest foreign publications. However, from a negative perspective, these figures also show that, compared with other disciplines, China's public administration possesses a greater degree of foreign influence and a lower degree of indigenisation. At present, the concepts, basic hypotheses, analytical framework, and research methods used in public administration have mostly originated from the West. By contrast, mainstream Western public administration does not stoop to discuss questions raised by Chinese administrative scholars. This contrast reflects not only Western academic hegemony but also China's own inability.

An indigenised public administration should absorb foreign nutrients critically, whilst it should also remain clearly aware of Chinese issues, think creatively about administrative phenomena in China and the world from a unique perspective, have the courage to elevate the results of such thinking into general theory, and consciously create new keywords, new conceptual systems, new basic assumptions, new analytical frameworks, and new methodologies in the course of developing theory. It should also have the self-confidence to conduct an active dialogue with foreign administrative scholars to share Chinese views on China and the world. In short, the requirements of indigenisation comprise three points: critical absorption of outside influences, creative thinking, and communicating as equals. 
I fully agree with Dao Minh Chau, who cautions against developing countries becoming cheap imitations of the West. According to Chau, "the modern features were imported from the West into a Confucian framework of thinking and were modified according to the spirit of Confucianism. The combination of Confucian and western administrative concepts has helped make Confucian countries successful in the administration of their development processes. In this case, culture is an advantage for development. Developing countries should find out from their cultural traditions what potentialities exist and effectively make use of them. Developing countries should avoid becoming cheap imitations of the West." (Chau, 1996, pp. 63-64).

Uniqueness does not exclude universality, and the latter must be discussed within the context of unique features of individual countries. We also recognise that state systems in general and prevalent values in particular are important determining factors of public administration development. Disciplinary development does extend beyond national boundaries (Wu et al., 2016). Robust development of Chinese public administration shall be based on and supported by both Chinese and foreign engagement in academic research and government practice. Likewise, global public administration shall benefit from greater exposure to Chinese experience (Wu et al., 2016).

Only in this way is it possible for Chinese public administration scholars to join in and contribute to the growing global effort to create a truly international public administration theory that goes beyond the Euro-American centrism that currently characterises contemporary administrative thought (Zinke, 1999).

\subsection{Adjustment of Dominant Theories Should be Made Timely}

As noted previously, the various schools of thought in Western administrative theories emerged in the wake of changes in governance realities. The takeaway for the Chinese public administration circles is that the renewal or development of the relevant theories must closely follow the practice of reform and opening up. For example, when the party-state adjusts the policy guideline from "giving priority to efficiency with due consideration of equality" to "both efficiency and fairness", the paradigm of public administration should be changed accordingly from overemphasizing instrumental rationality to merging the value and instrumental ra- 
tionalities. In this way, administrative theories can be expected to provide strong support to governance practice.

Examining the developmental path of Chinese public administration, it becomes clear that public administration practice determines the directions of public administration research and studies. Although the discipline and practice are highly correlated, the discipline is lagging behind severely. This can be further confirmed with a brief time-series description below. With regard to public administration practice, China has experienced eight rounds of administrative reforms in five-year intervals, from 1982 to 2018. Accordingly, these administrative reforms are important research topics and frequently appear in the journal Chinese Public Administration. However, academic concerns with these administrative reforms are expressed around a year following the execution of the reforms. The reforms become a research concern only once they have been carried out. This indicates that the Chinese public administration circle, though responding to reality well, has little influence in terms of leading public administration practice in advance. This phenomenon is also acknowledged by the discipline-framers in China. In a key research project report, examining the key areas and topics of Chinese public administration, the authors, Chen Zhenming and Xue Lan - leading authorities in this area clearly pointed out that Chinese public administration is currently unable to play an initiatory role in leading public administration practice (Chen $\&$ Xue, 2007).

\section{Conclusion}

Western scholars have asked whether China can achieve its socio-economic transition in a smooth and stable fashion, now that it has entered a stage of modest growth in the wake of decades of high growth. Given the frequent mystification of the Chinese "experience" or "miracle", these rhetorical and substantive questions have become a concern of the international research community. Similar doubts also refer to the field of public administration.

Chinese public administration is facing an "identity crisis". At this stage, it is key that it should develop its own unique paradigm, including concepts, theories, and methodologies, and contribute to the progress of the whole discipline. Despite the challenges it is facing, Chinese public administration also has great prospects. China's development, the requirements of 
PA practice, and puzzles of public administration theories all breed opportunities. The accelerating deepened process of globalisation and new information technologies are facilitating the interaction between Chinese public administration and global scholarship, and the theoretical foundations of China's public administration could be stabilised through these interactions. Its future depends on whether it can form its own theoretical framework and dialogue with global scholarship. It is important to maintain an open and competitive environment within this process.

In this respect, Dao Minh Chau's insight into the dual impact of cultural tradition should be particularly appreciated. As he explains it, cultural tradition does not only hold potential for development, but can also be an obstacle to development. Some traditions can be positive in one stage of development, but negative in others. The authoritarian style of administration, with its emphasis on economic progress rather than on democracy, was positive in the first stage of development. It is, however, difficult to believe that this style will continue to be positive as the community becomes more educated and more affluent, and as information technology makes the world become more interrelated, and people can more readily compare conditions in their society with those in other countries. The lesson here is that developing countries should creatively assess their cultural legacy and decisively criticise and refute those features which block development. The most effective way to do this is to study their own history, as well as the experience of other nations, in a careful and critical fashion. (Chau, 1996, pp. 63-64)

In conducting public administration research over the past four decades, Chinese scholars have become used to playing the role of consumers of imported concepts, theories, and methods. Indigenisation is urging our Chinese colleagues to challenge themselves in order to consciously engage in independent theoretical thought. I hope that in the near future Chinese public administration circles will not only be able to fully express themselves, but also to become producers and exporters of concepts, methods, theories, and ideas.

\section{References}

Bo, G. (1998). Chinese administration science: Problems, challenges and countermeasures. China Public Administration, 168(12), 6-9.

Bodenheimer. E. (1999). Jurisprudence: The philosopby and method of law. Beijing, China: China University of Political Science and Law. 
Central Committee, Communist Party of China (1993). Decision on some issues regarding the establishment of the socialist market economy adopted by the Third Plenum of the Fourteenth Central Committee on November 14, 1993, http://cpc. people.com.cn/GB/64162/134902/8092314.html

Chau, D. M. (1996). Administrative concepts in Confucianism and their influence on development in Confucian countries. Asian Journal of Public Administration, 18(1), 45-69, https://doi.org/10.1080/02598272.1996.10800317

Chen, Z., \& Xue, L. (2007). The key fields of theoretical research of China's public administration. Social Sciences in China, 339(3), 140-152.

Cheng, J. (2011). Themed transformation: Analysis of the current research of administration science in China: Case study of China public administration. Nanjing Technology University Journal (Social Sciences), 37(1), 41-43.

Christensen, T., Dong, L., \& Painter, M. (2009). Administrative reform in China's central government: How much "learning from the West"? International Review of Administrative Sciences, 74(3), 351-371, https://doi.org/10.1177/0020852308095308

Christensen, T., Dong, L., Painter, M., \& Walker, R. (2012). Imitating the West? Evidence on administrative reform from the upper echelons of Chinese government. Public Administration Review, 72(6), 798-806, https://doi. org/10.1111/j.1540-6210.2012.02582.x

Deng, X. (1994). Selected works of Deng Xiaoping. Beijing, China: People's Publishing House.

Dong, L. (2015). Public administration theories: Instrumental and value rationalities. New York, NY: Palgrave Macmillan.

Dong, L., Christensen, T., \& Painter, M. (2014). Health care reform in China: An analysis of development trends and lack of implementation. International Public Management Journal, 17(4), 493-514, https://doi.org/10.1080/10967494.2014. 958802

Frederickson, H. G. (2002). Confucius and the moral basis of bureaucracy, Administration \& Society, 33(4), 610-628, https://doi.org/10.1177/0095399702336002

Frederickson, H. G. (2003). The spirit of public administration. Beijing, China: China Renmin University Press.

He, Y. (2008). What kind of research are we doing: A review of the researches on Chinese administration science (1995-2005). In Ma Jun \& Hou Yilin (Eds.), Public Management Research. Shanghai, China: People's Publishing House, pp. 21.

He, Ying (2005). Methodology in public administrative research and an analysis on its trend. Chinese Public Administration, 250(10), 104-108.

Henry, N. (2011). Public administration and public affairs. Beijing, China: China Renmin University Press.

Holzer, M. (2001). The preface to the "Public Administration Research Methods" column. Chinese Public Administration. 212(8), 40-41.

Jing, Y. (2009). History and context of public administration in mainland China. In E. Berman, M.J. Moon and H. Choi (Eds.), Public administration in East Asia: Mainland China, Japan, South Korea and Taiwan (pp. 33-54). Boca Raton, FL: CRC Press, https://doi.org/10.1201/ebk1420051902-c2 
John, P., Cotterill, S., Moseley, A., Richardson, L., Smith, G., Stoker, G., \& Wales, C. (2011). Nudge, nudge, think, think: Experimenting with ways to change civic behaviour. London, United Kingdom: Bloomsbury, https://doi. org/10.5040/9781849662284

Liu, W., \& W. Li. (2013). Public administration in China: Evolution and current challenge. Asian Journal of Political Science 21(1), 1-20.

Ma, J. (2012). Research on the Chinese administration science: Reflection \& prospects. Journal of Public Administration. 25(1), 38-45.

Ma, J., \& Liu, Y. (2007). The identity crisis of the Chinese public administration science. Journal of China Renmin University, 124(4), 38-41.

Ma, J., Zhang, C., \& He, Y. (2009). Reflection on the Chinese administration science: Crisis and reconstruction. Beijing, China: Central Compilation \& Translation Press.

O'leary, R. (2011). Focusing the public leadership lens: Research propositions and questions in the Minnowbrook tradition. Journal of Public Administration Research and Theory, 21(suppl_1): i1-i6, https://doi.org/10.1093/jopart/muq066.

So, Y. L., \& Walker, A. (2006). Explaining Guanxi: The Chinese business network. New York, NY: Routledge.

Stout, M. (2006). A samurai's lineage: Theoretical traditions in public administration, Administrative Theory \& Praxis, 28(4), 618-630, https://doi.org/10.1080/ 10841806.2006.11029547

Tao, J. L. (2016). Decentralizing unitary governments without a map: "Learning how to salsa when we only know how to waltz". Croatian and Comparative Public Administration, 16(4), 743-771, https://doi.org/10.31297/hkju.16.4.6

Walker, R. M., Brewer, G. A., \& Choi, Y. (2013). Public administration research in East and Southeast Asia: A review of the English language evidence, 19992009. The American Review of Public Administration, 44(2), 131-150, https:// doi.org/10.1177/0275074013497088

Wang, W., \& Zhao, Z. (2012). Rural taxation reforms and compulsory education finance in China. Journal of Public Budgeting, Accounting, and Financial Management, 24(1), 136-162, https://doi.org/10.1108/jpbafm-24-01-2012-b007

Wu, X., He, Y.-L., \& Sun, M. T.-W. (2013). Public administration research in mainland China and Taiwan: An assessment of journal publications, 19982008. Public Administration, 91(2), 261-280, https://doi.org/10.1111/j.14679299.2011.01978.x

Wu, J., Hou, Y., \& Ma, L. (2016). The rise of public administration in China since 1978: Driving forces, problems and prospects. Journal of Chinese Governance, 1(2), 214-227, https://doi.org/10.1080/23812346.2016.1166904

Xie, Q. (1993). Chinese public administration: Misunderstanding and implications. International Journal of Public Administration, 16(9), 1431-1458, https:// doi.org/10.1080/01900699308524854

Xue, L., He, H., \& Yang, L. (2008). Accumulation and astride: Macro management and policy research compendium under the guidance of the scientific concept of development. Beijing, China: Science Press. 
Yan, C., \& Niu, M. (2009). Normative research in the public administration science. Journal of Public Administration, 7(1), 105-128.

Yuan, F. (1997). Tutorial on social science research methods. Beijing, China: Peking University Press.

Zhang, C. (2007). Reconstruct the public theory of public administration. Journal of China Renmin University. 124(4), 1-2.

Zhang, K. (2002). Search for the etbical perspective of public administration. Beijing, China: China Renmin University Press.

Zhang, W., Xiaolin, X., Evans, R., \& Feng, Y. (2017). Towards internationalization: A Critical assessment of China's public administration research in a global context 2000-2014. International Public Management Journal, https:// doi.org/10.1080/10967494.2016.1276036

Zhou, D. (2000). On assumption about human nature. Journal of Guangxi University 132(6), 1-8.

Zinke, R. C. (1999). Looking beyond the mirror: Toward an international public administration theory. Administrative Theory \& Praxis, 21(3), 371-376, https:// doi.org/10.1080/10841806.1999.11643385 


\section{INSPIRATION FROM THE DEVELOPMENT OF PUBLIC ADMINISTRATION IN THE WEST FOR STUDIES OF PUBLIC ADMINISTRATION IN CHINA}

\section{Summary}

Many Western-based theories of public administration have had some traction in the Chinese setting. However, they also point to the importance of context and the need to ensure that the theory is relevant to the setting. In this regard, theory needs to be both clearly developed and there are various routes that can be taken. In this article, I share with readers some of my thoughts emanating from my teaching and research over the past two decades, namely, inspiration from the development of public administration in the West for studies of public administration in China. The two analytical lenses that I use for this article are the five essential attributes of public administration and the instrumental and value rationalities as the fundamental nature of the various schools of thought in the development of public administration in the West. The five essential attributes refer to core value, assumptions about buman nature, methodology, government role, and disciplinary positioning. They serve as references for my review of the field of public administration in China. Over the last four decades, public administration research in China has resulted in the restoration of the discipline, the flourishing of teaching and research programmes, and active exchanges with colleagues around the world. However, Chinese public administration is facing an "identity crisis". Chinese scholars have become used to playing the role of consumers of imported concepts, theories, and methods. At this stage it is urgent that they develop their own unique paradigm, including concepts, theories, and methodologies, and contribute to the progress of the whole discipline. The goal of forming their own theoretical framework is urging our Chinese colleagues to challenge themselves to consciously engage in independent theoretical thought. More specifically, they should try to keep abreast of the theoretical developments in the West and lay emphasis on cutting-edge research, avoid not seeing the forest for the trees, and practise timely adoption of dominant theories.

Keywords: public administration theories, China, the West, tradition, reform and opening up, imitation, indigenisation 


\section{RAZVOJ JAVNE UPRAVE NA ZAPADU KAO POTICAJ ZA PROUČAVANJE JAVNE UPRAVE U KINI}

\section{Sažetak}

Mnoge su zapadnjačke teorije o upravnoj znanosti stekle određenu popularnost u Kini, no one također ukazuju na važnost konteksta $i$ potrebu da teorija bude u skladu s okruženjem u kojem se primjenjuje. U tom bi smislu svaka teorija trebala biti jasno razradena, što se može postići na više načina. U radu autor navodi neka razmišljanja koja proizlaze iz njegovog nastavnog $i$ istraživačkog djelovanja tijekom protekla dva desetljeća. Radi se o načinima na koje je razvoj upravne znanosti na Zapadu potaknuo pristupe proučavanju upravne znanosti $u$ Kini. U radu se razmatra pet ključnib značajki znanosti o javnoj upravi te instrumentalni $i$ vrijednosni elementi kao osnovne karakteristike različitib škola mišljenja koje su se bavile razvojem ovog znanstvenog polja u zapadnim zemljama. Tib su pet ključnib značajki središnja vrijednost, pretpostavke o ljudskoj prirodi, metodologija, uloga vlasti $i$ pozicija discipline, te se pomoću njib nudi pregled područja upravne znanosti u Kini. U posljednja su četiri desetljeća istraživanja Kineza u ovom području uspjela povratiti ugled upravnoj znanosti $i$ rezultirala naglim rastom broja studijskib $i$ istraživačkib programa, kao i razmjenom iskustava s kolegama diljem svijeta. Unatoč tome, kineska znanost o javnoj upravi suočava se s "krizom identiteta" jer su kineski znanstvenici navikli na ulogu potrošača uvezenib znanstvenib koncepata, teorija i metoda. U ovome je trenutku iznimno važno da Kina razvije vlastitu paradigmu, uključujući koncepte, teorije $i$ metode, te da doprinese razvoju cjelokupnog znanstvenog polja. Nastojanja da osmisle vlastiti teoretski okvir potiču Kineze da si postavljaju izazove $i$ svjesno formuliraju teorijska razmišljanja neovisno o drugima. Da budemo precizniji, Kinezi bi trebali biti tijeku s razvojem teorija na Zapadu $i$ usredotočiti se na najnovija istraživanja. Takoder bi trebali izbjegavati fokusiranje na određene teorije zanemarujući cjelokupni razvoj $i$ pravodobno pribvaćati prevladavajuće teorije.

Ključne riječi: teorije o upravnoj znanosti, Kina, Zapad, tradicija, reforme $i$ otvaranje prema drugima, imitacija, indigenizacija 